\title{
THE FUTURE OF THE DEVELOPMENT OF PESTICIDES BY INDUSTRY*
}

\author{
E. KNÜSLI \\ CIBA-GEIG Y Ltd, Basle, Switzerland
}

\begin{abstract}
The growing and in many regions undernourished world population will necessitate a full mobilization of the world's agricultural resources in future even more than in the past. The fight against harvest depressing factors is among the most important measures for reaching this objective. There is striking evidence that the use of suitable chemicals will remain, in the frame of these endeavours, a most important weapon also in the time to come. New agricultural chemicals to be developed have to satisfy increased requirements as to performance and compatibility with the environment. This situation makes research and development for such chemicals a most expensive operation bearing high industrial risks with respect to the probability of success. There is a range of companies who are willing to accept the challenge; a tendency to a diminution of this range has been observed, however, in the recent past.

The companies engaged in such research and development are aware of their responsibility to explore the products to be commercialized according to the best technological expertise available, and to judge facts and findings in an objective manner. Their activity depends, however, on conditions such as for example:

-operable regulation requirements imposed by the legislator;

- an adequate system of protection of technical property;

the scrutiny and objectivity of the information media.

The industry involved in agricultural chemistry intends to intensify directly or through mediators the dialogue with the public. The risks of uncritical, emotional technophobia should not be underrated; consciously applied technology will be a prerequisite for survival.
\end{abstract}

At events such as this congress, Industry is usually featured below the title of a paper. Here, however, Industry appears in the title, in connection with the future of the development of pesticides. The problem is: should we or should we not try to develop new agricultural chemicals, for example pesticides, herbicides, plant growth regulators, in the future? Let us first exchange views whether we, that is the world's population, will need such chemicals in the future, be they new or established ones. This question is necessary at the very beginning of our discussion because our industry is oriented towards serving existing or anticipated needs. We sometimes unveil hidden needs. We do not create needs purposely. It was nobody's intention to make some strains of insects resistant. We did not import the water hyacinth into Florida in order to build up a new market.

\footnotetext{
* Paper given on behalf of GIFAP (Groupement International des Associations Nationales de Fabricants de Pesticides/International Pesticides Manufacturers' Association). The version designed for lecturing was adapted for printing by the Editor.
} 


\section{E. KNƯSLI}

To obtain an answer to the question of need, we cannot escape making some reflections on the scene of the future.

Today, the health and productivity of crop plants and domestic animals are the target of our activity and interest. In 10 or 20 years from now will: crop plants still be major suppliers of food and feed? domestic animals still be major suppliers of proteins? some plants still be important sources of textile fibres?

There is no doubt that the importance of substitutes or alternatives will increase in the decades to come, and new developments in this field may even become a necessity. The opinion of the experts is, however, unanimous, that traditional agricultural production will maintain its dominant position.

Will the world's population need more or less food and clothing 10 or 20 years hence than it does today? Recent figures from the Population Reference Bureau, Washington, are more striking than any comment (Table 1).

Table 1. World's population in millions

\begin{tabular}{lrrl}
\hline & 1972 & Projection 1985 & Increase \\
\hline Africa & 364 & 530 & $+46 \%$ \\
Asia & 2154 & 2874 & $+33 \%$ \\
North America & 231 & 274 & $+19 \%$ \\
Latin America & 300 & 435 & $+45 \%$ \\
Europe & 469 & 515 & $+10 \%$ \\
Russia & 248 & 287 & $+15 \%$ \\
Oceania & 20 & 27 & $+35 \%$ \\
World & 3786 & 4942 & $+30 \%$ \\
\hline
\end{tabular}

Source: Population Reference Bureau, Washington

When looking at these figures one should be reminded that according to the FAO, even today, only a part of the world's population enjoys sufficient or abundant food. Dr Boerma stated early this year that calorie-wise 10-15 per cent (more than 400 million people) are undernourished. And hundreds of millions more have a protein and vitamin deficiency.

After 10 or 20 years will insects, spider mites, weeds, fungi, nematodes, bacteria, viruses still exist and be a threat to man, so that he has to mobilize antagonistic measures? Most experts agree that man will still be confronted with them in the future, mercilessly.

Remember : today he loses more than a third of the world's crop to pests and weeds; in Asia (excluding China) 172 mio (i.e. $10^{6}$ ) tons of rice per year; in the USA 43 mio tons of corn per year, and remember too: one swarm of grasshoppers may devour 3000 tons of plant material a day.

After 10 or 20 years, will chemicals still play an important role in the fight against pests and weeds, and for abundant crops and healthy domestic animals? Before giving an answer to this question, a judgement on the present position of chemical pesticides is needed. No reasonable man has ever postulated that chemicals should be considered the only meaningful way of coping with pests and weeds. All suitable measures for reaching the objective safely and effectively must be considered, and especially measures which are complementary to one another. The idea of a so-called integrated 
pest-control approach is not new-it has been advocated for two decades. Methods other than chemical will receive due attention and will lead to useful new evidence. On the other hand, neither scientists nor farmers nor officials feel that chemicals can substantially, easily or quickly be replaced by any other technique. There is strong evidence that chemicals will maintain an important place in the fight against pests and weeds for the foreseeable future.

Should we press on, therefore, to discover and develop new chemicals? We have first to consider additional factors. It seems obvious that agricultural chemicals will still be needed in the future, but is there a need for new chemicals? What are our responsibilities when we decide to engage in finding new chemicals? What are the risks we run when trying to find new chemicals? What are the conditions we have to impose in accepting the challenge of the responsibility and the risk?

Today, we have available a relatively broad range of suitable chemicals for the solving of many important agricultural problems. Some of them do their job in an acceptable way, some do it in an outstanding way. In many fields market penetration is high. Industry has been extraordinarily inventive in the last two decades; on the other side product obsolescence is relatively low. In view of this situation it is, today, obviously not easy for the talents of more than 50 companies to be successful with new developments. What are their aims? There are still some important gaps to be filled. There is room for the replacement of compounds with acceptable performance by products with outstanding performance. Recent evidence with respect to unsatisfactory environmental behaviour of some existing products or product classes raises the need for substitutes. New prototypes of

Table 2. Review on safety studies

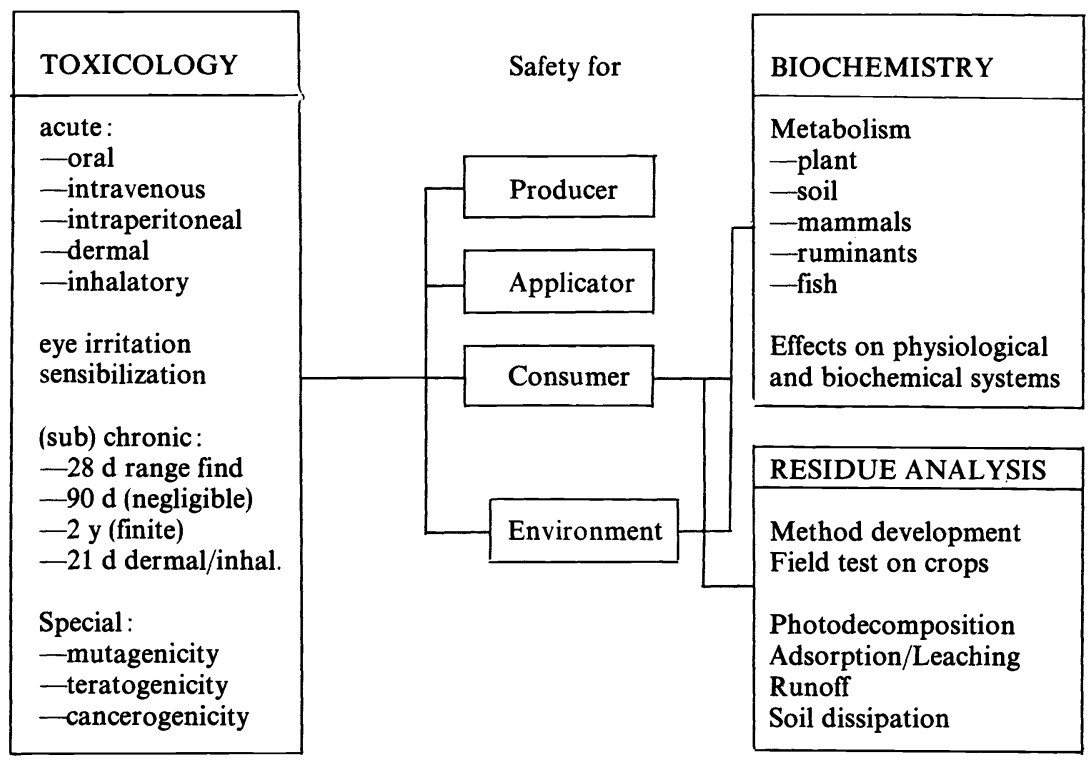

Source: Geissbühler H., CIBA-GEIGY Ltd, Basle 


\section{E. KNÜSLI}

chemicals may allow fundamentally new approaches to the solution of the problems. We must conclude that there are opportunities for new products but they have to compete with a high level of existing technology.

What are the obligations and responsibilities we have to accept when we decide to search for new chemicals?

We must generate products with a high standard of biological performance and with an economical feasibility. We must document the products proposed for commercial introduction with respect to their safety and risks with regard to plants, animals, humans and the environment (Table 2). For this purpose we are obliged to make use of the best available scientific expertise.

Biochemical units examine questions of metabolism and of the effects on physiological and biochemical systems. Analytical units study the quantitative aspects. Toxicological units evaluate not only the safety of the consumer but also of the producer and the product user.

Biochemistry and analysis usually follow three typical product pathways and by them the formation of metabolites (Table 3).

Table 3. Pathways of pesticides in the environment
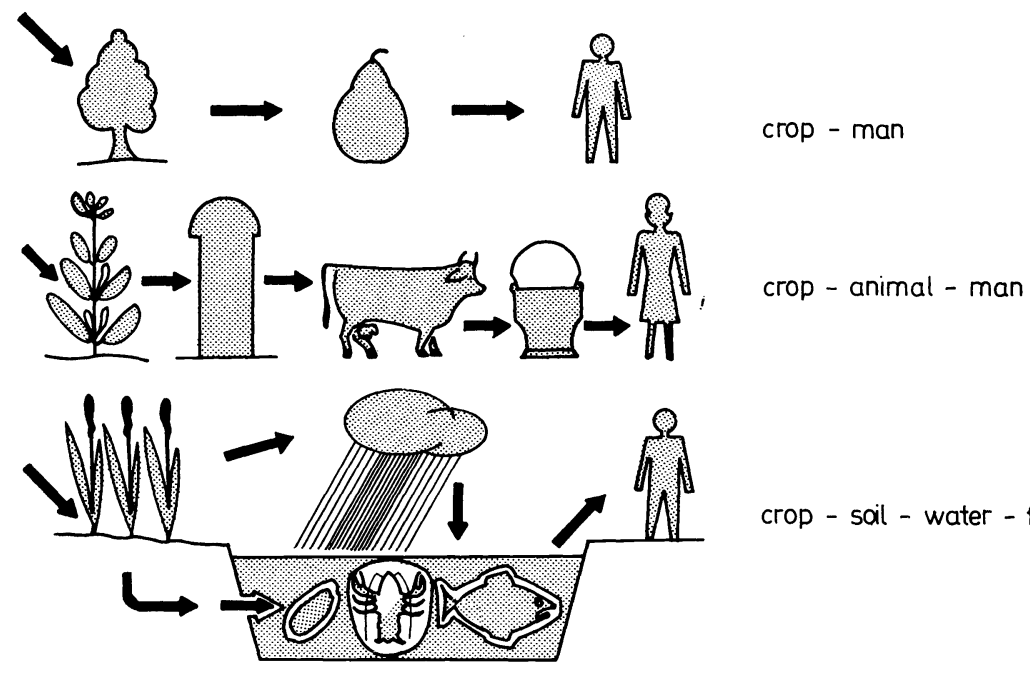

crop - sail - water - fish - man

Source : Geissbühler H., CIBA-GEIGY Ltd, Basle

As an illustration of the technical possibilities of our time which enable us to follow the fate of a molecule, the degradation of the triazine herbicide Atrazine $^{\mathrm{R}}$, summarized in Table 4, may be of interest. More than 1,500 scientific papers have been published, dealing with studies on the behaviour of Atrazine in the environment. 
Table 4. Simplified scheme of degradation of Atrazine ${ }^{\circledR}$
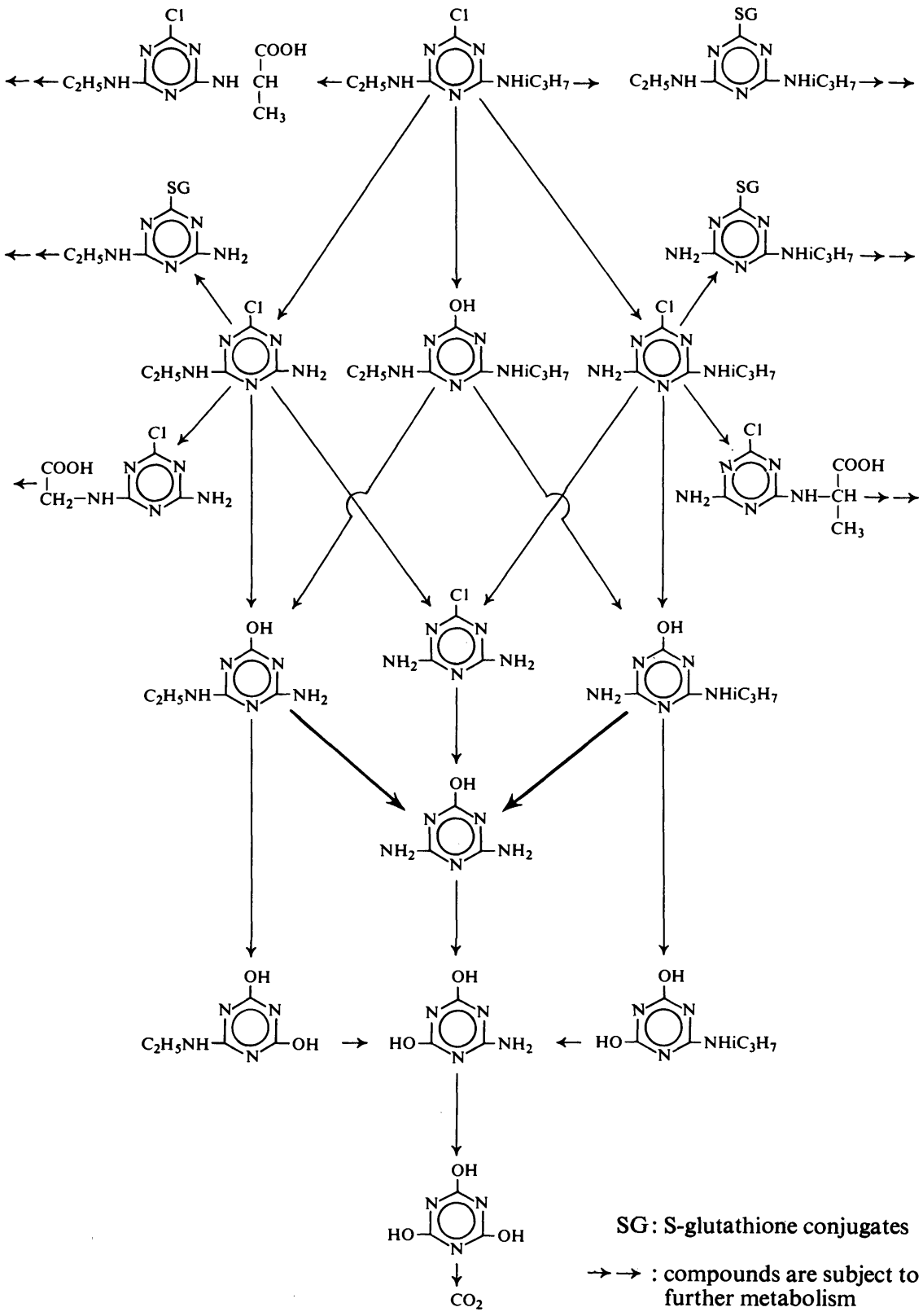

Source:

Esser et al., "s-triazine" in Herbicides: Chemistry Degradation and Mode of Action, P.C. Kearney/D.D. Kaufman, edits., Marcel Dekker Inc., New York, 2nd edition to be published. 


\section{E. KNƯSLI}

Such a thorough documentation is unusual and is linked to the wide use of the product. It must also be noted that such a volume of studies could never be provided by an originator company; in this case it is largely due to a broad range of interested university and experimental station scientists. Furthermore the fantastic sensitivities our analysts can sometimes reach, depending on the structure, even detecting amounts down to parts per $10^{9}$, cannot to be taken as a general standard.

We have to familiarize the product user with the possibilities and the limitations of the chemical tools by adequate documentation and education. A great many of the achievements of our modern age can do either good or bad depending on the brains and hands which make use of them. The responsibility of the originator or the producer to provide information and knowhow for the correct use of the product becomes only effective if the user is willing to take notice of it. Nobody should be allowed not to read labels.

Which are the risks we will encounter and will have to accept when we decide to try to find new chemicals? As a consequence of the high level of existing technology, mentioned above the probability of success in finding a product with the desired superior properties is low. A representative survey claims that only one compound out of 10000 compounds synthesized and examined may reach the level of practical use. The time that this perhaps successful compound needs to progress from the test tube to the user may, by a series of happy coincidences, last only four years but is more often up to eight years.

Even though every effort is made to eliminate unsuitable candidates as early as possible on the development ladder, we will not be sure until the last phase before registration whether a compound will be acceptable or not. Some incalculable factors can be crucial and build up insurmountable obstacles. Elanco Products Co. of Eli Lilly and Co. discovered in the late 'sixties an outstanding new fungicide coded EL-273. It was a chemical pioneer and showed, biologically, a broad spectrum of activity at a low dosage which had seldom been met before. In the last phase of the toxicological evaluation it became evident, however, that the compound offered unacceptable risks so that the company had to drop it.

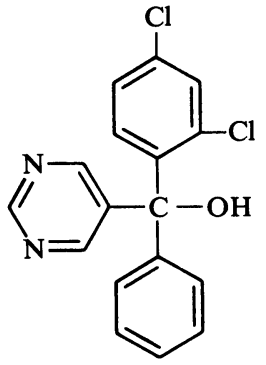

EL-273

Triarimol

Trimidal $^{\mathbf{R}}$

Eli Lilly \& Co.

Belg. Pat. No. 714003

The scientific and industrial achievement of the group who discovered EL-273 merits respect and recognition. Bad luck ended a potential breakthrough development. The company claimed to have invested 20 mio dollars 
in the product. This figure shows that the cost of the finding and developing a new agricultural chemical has been reported in a rather conservative way by other sources which recently spoke of 5-10 mio dollars. It must be kept in mind that the few successful developments have to pay for and to carry all the losers which show no effect at all or are eliminated for various reasons in the successive phases of product evaluation.

The risk we take is, therefore, in the end that of a substantial financial engagement with many unknowns on an eventual return. The question reduces to whether we can invest and whether we want to invest in the development of new pesticides. Let us assume that funds are available and that, in view of the needs identified earlier, we propose to try. This is one decision possibility; in good faith and with good reasons the opposite can be taken, too. Olin Mathieson chose the latter alternative as did Hooker, Allied, Mobil Oil, Air Products, Esso, American Oil, Thompson Chem., and Chapman. They decided to make no further research and development efforts in the field of agricultural pesticides and herbicides. We, too, with our 'go' decision cannot be free from care and preoccupation. We must do our utmost to contribute within a reasonable time so that cash will be available in the future. If we are a private enterprise, every last cent we need has to be generated by ourselves. We need money to provide, run and renew suitable working facilities, we need modern, inevitably expensive equipment. We have to pay our co-workers a decent compensation and to care for their welfare. Nobody will give us money à fonds perdu; some people may lend us, trustfully, some starting capital. If we fail, they will lose it. If we are successful, they merit a certain recompense. This last point gives us the status of a capitalistic organization, and we are or will be in this connection reproached for being profit-minded or profit-possessed. Let us not forget the proportions. These are illustrated strikingly by the figures given in the annual report of a Swiss chemical company with which I have some relationship (Table 5).

Table 5. Financial characteristics from the annual report of a Swiss chemical company active in the fields of dyestuffs, plastics and additives, pharmaceuticals, agrochemicals and photography.

\begin{tabular}{llcc}
\hline Turnover 1972 & $\mathrm{SFr}$. & $8064 \mathrm{mio}$ & \\
$\begin{array}{l}\text { Salaries to more than } 71000 \\
\text { employees }\end{array}$ & $\mathrm{SFr}$. & $2615 \mathrm{mio}$ & $32.5 \%$ \\
$\begin{array}{l}\text { Investments in working and } \\
\text { production facilities }\end{array}$ & $\mathrm{SFr}$. & $732 \mathrm{mio}$ & $9 \cdot 1 \%$ \\
\begin{tabular}{l} 
Dividend to stockholders \\
\hline
\end{tabular} & $\mathrm{SFr}$. & $91 \mathrm{mio}$ & $1.1 \%$ \\
\hline
\end{tabular}

If we are willing on the one hand to take on the responsibilities and risks described then we are forced, on the other hand, to formulate the conditions under which we can accept them. There are two main conditions :

(1) The hurdles inherent in the project on the way to finding and developing an agricultural chemical are manifold and high. The hurdles set by institutions external to the project should be fair.

This relates mainly to the sphere of product registration. As potential originators of new pesticides we have already committed ourselves to exploring the products according to the best scientific expertise available before 


\section{E. KNƯSLI}

introducing them to the general market. We need to do this not only for our proper conscience but also in our own real interest. Who would like to be confronted, after commercialization and after having made the efforts for promotion, production and introduction, with compromising facts, with harm done? But the requests made for product characterization should be reasonable and meaningful. Based on the recent trends observed we can expect, in general, an open-minded dialogue with the majority of the registration bodies. But improvement is still possible. It would, for example, be extremely helpful if a common line for the qualification and classification of toxicological parameters could be established worldwide. Some countries aim at isolated schemes which differ from those of the representative majority.

A further area relates to the acceptance of data depending on their origin. Local data are, of course, necessary to document the performance and the residual behaviour of a compound. On the other hand, data which are and have to be established under controlled, reproducible conditions should be accepted worldwide with the proviso that they are elaborated by qualified institutions. This concerns especially the data of toxicological and pharmacological experiments and studies of metabolism.

What about the size of the documentation required for registration?

Table 6. Increase of the minimum registration requirements

\begin{tabular}{|c|c|c|c|}
\hline & 1950 & 1960 & 1970 \\
\hline Toxicology & $\begin{array}{l}\text { Acute toxicity: } \\
30-90 \text { day, rat }\end{array}$ & $\begin{array}{c}\text { Acute toxicity: } \\
90 \text { day, rat } \\
90 \text { day, dog } \\
2 \text { year, rat } \\
1 \text { year, dog }\end{array}$ & $\begin{array}{l}\text { Acute toxicity: } \\
90 \text { day, rat } \\
90 \text { day, dog } \\
2 \text { year, rat } \\
2 \text { year, dog } \\
\text { Reproduction, } \\
3 \text { gen., rat } \\
\text { Teratogenesis, } \\
\text { rodent } \\
\text { Fish, shellfish, } \\
\text { etc. } \\
\text { Birds }\end{array}$ \\
\hline Metabolism & & Animal (min.) & $\begin{array}{l}\text { Rodent, and/or } \\
\text { dog } \\
\text { Plant }\end{array}$ \\
\hline Analytical & $\begin{array}{l}\text { Food crops, } \\
1 \text { p.p.m. }\end{array}$ & $\begin{array}{l}\text { Food crops, } \\
0 \cdot 1 \text { p.p.m. } \\
\text { Meat } 0 \cdot 1 \text { p.p.m. } \\
\text { Milk } 0 \cdot 1 \text { p.p.m. }\end{array}$ & $\begin{array}{l}\text { Food crops } \\
0.01-0.05 \text { p.p.m. } \\
\text { Meat } 0.1 \text { p.p.m. } \\
\text { Milk } 0.005-0.05 \text { p.p.m. }\end{array}$ \\
\hline Ecology & & & $\begin{array}{l}\text { Environmental } \\
\text { Stability } \\
\text { Movement } \\
\text { Spectrum }^{c} \\
\text { Accumulation }\end{array}$ \\
\hline
\end{tabular}

a denotes pesticide only.

b denotes pesticide plus toxic metabolite(s).

c denotes number of species affected-specific or broad range of toxicity.

Source: Johnson J. E. and Blair E. H. 'Cost, time and pesticide safety'. Chem. techn. p. 666 (November 1972) 
Johnson and Blair have recently illustrated (Table 6) the dramatic increase of USA minimum registration requirements during the past two decades.

The justification of a thorough product evaluation has been confirmed already. Nevertheless, the picture is impressive. Care must be taken that such lists, wherever they are established, remain manageable. Any further addendum has to be more than critically reviewed. Experimental models which have been recognized as unsuitable should be abandoned. A stepwise requirement of safety documentation linked with the various phases of product registration would save money from non-performers and save time with performers. The idea that the study of some items out of the bundle of requirements might be connected with a critical market size of a product also merits further consideration. No-residue situations, too, would justify a shortening of the list. For example, the development of specific, narrowspectrum products as desired for integrated pest control programmes is highly questionable when burdened with the load of the full documentation.

(2) The chances for a commercially successful achievement are low. The risk-taker has to be assured, for the reasons explained, of adequate returns, and this means that for his successes he should have exclusive rights during a substantial period of the product life.

Patent granting is an instrument towards this aim. The agreement of a broad range of European countries - unfortunately questioned now by British reservations - to establish a European Patent would be an important step forward with respect to harmonizing practice in different countries and with respect to ease of administrative handling. In view of the quantitative overloading of many patent offices the importance of the last-mentioned point should not be underrated. On the other hand there are still important countries in which no practicable system for the protection of industrial invention exists. In an increasing number of countries, trends for instituting completely illusive terms of patent life may be observed. When the development of a new product may continue for up to eight years, patent terms of only a few years, as proposed and discussed, would not mean any preferential treatment for the originator. It would mean, on the contrary, a punishment of his entrepreneurship. Compulsory licensing, unrealistic definitions of the exercising of patents, based on these, automatic lapses or invalidity statements, and finally retroactive changes in the interpretation of patent laws, are further fundamental factors which could be deadly for further initiative for industrial innovation.

The easy access to official files with important basic information, obtained by original, tedious, costly studies, by second registrants is another threat to originators which could have serious consequences.

The observation of the two conditions described is, as I have already emphasized, vital for the industrial engagement discussed. The next postulate, in the form of a modest wish, is important, too. Its accomplishment would ease the endeavours of all those who work honestly to solve the problems and to serve the needs defined. I allude to the discussion of our industrial achievements by the public and to the part of the mass media in this discussion. The role of modern technology in all our lives and the pros and cons, merit and need debate. Chemical pesticides - like other pest control measures, by the way-are part of modern technology. Under present conditions they 


\section{E. KNÜSLI}

contribute to the fulfilment of some of the genuine, primitive desires of man: health, food, clothing. The dialogue on such a serious topic should be de-emotionalized. It should be put on the basis of an insatiable desire to know the truth behind observed phenomena, and it should be dealt with factually, not by making assumptions and speculations. In this connection I would like to appeal to the responsibility of scientists, to whichever party they may belong. It would be a crime to be qualified for and not to draw the attention of public opinion to problems; but it is also a crime to mislead public opinion. In this discussion we need expertise. An eminent representative of what is named nowadays environmentalism once wrote to me: 'Is it true that Pyrethrum can be used for the production of DDT?' In this discussion we need and ask for fairness. The same environmentalist asserted, and was quoted in daily newspapers, that insecticides would be ten times more toxic under tropical conditions than elsewhere. When asking for the background data for this statement, I received the reply that he would like the respective experimental results from me. One becomes popular by accusing agricultural chemicals. This has been recognized also by various politicians. It is also simple to accuse agricultural chemicals. I quote a case in Canada when the anger of public opinion was turned against a Metropolitan Forestry Division who had started an insecticide spraying programme, because, regrettably, some dead wild ducks were discovered and the deaths were attributed to this action. It needed a complete detective approach to reveal that the ducks were found before the first treatments had occurred and that they had been killed by chloralose in connection with trapping by a Waterfowl Research Foundation. Recently, scientists of high reputation put their names to a statement in which the death of a group of reindeer was attributed to the brush control agent 2,4,5-T. Even before this a serious study had revealed that no connection between their death and the chemical agent could be established. Will the group of scientists have the fairness to make corrective statements?

With this last example I would like to emphasize positively the role, the importance and the responsibility of the mass media in the discussion on chemical pesticides. I know that they are confronted with one special aspect of our time or maybe of all times: the glamour of the negative. What is sound, healthy and positive can hardly serve as a headline or make an attractive story. Would it not be a challenge for the mass media to try this approach more often also in the field of our activity? Quoting the positive would not mean that question marks must be suppressed. Industry is aware that in the past it did not consider sufficiently the need for communication with the public directly or through the mass media. Industry is ready to intensify this dialogue and to do it in an open-minded and objective manner.

We are all members of the family of man. As such we want to survive, and we wish also that our children and grandchildren will survive. Again, therefore, not only our conscience but also our pure egoism obliges us to aim at effective and at the same time safe and wise solutions of problems. Science and technology have, not without cause, been brought down from the pedestal of uncritical glorification. Consciously applied they remain, however, decisive keys for mastering man's future. 


\section{RELATED READING}

A. H. Boerma, Wintertagung 1974 der Oesterreichischen Gesellschaft für Land- und Forstwirtschaftspolitik.

H. H. Cramer, 'Pflanzenschutz und Welternte'. Pf lanzenschutz Nachrichten Bayer, 20, 1 (1967).

Ernst \& Ernst Trade Assoc. Dept., Washington, DC, 'Pesticide Industry Profile Study'. NACA (May 1971).

D. G. Hessayon, 'Homo Sapiens-The Species the Conservationist Forgot.' 8th Tennant Memorial Lecture, Society of Chemical Industry: London (10 February, 1972); Chem. \& Ind. (20 May, 1972).

J. E. Johnson and E. H. Blair, 'Cost, Time and Pesticide Safety'. Chem techn., 666 (November 1972).

J. Kradel (BASF), 'Integrated Approaches as seen by a Pesticide Manufacturer'. EEP/TOBC/ WPRS Conference on Integrated Approaches in Plant Protection, Vienna (June 1973).

B. G. Lever and W. M. Strong (ICD), 'Evaluation of a Pesticide by a Chemical Industry'. EPPO Conference on Plant Protection Economy, Brussels (May 1973).

H. Metzger (BASF), 'Pflanzenschutz 1980 aus der Sicht der Industrie.' Chemie und Fortschritt, 3-11 (1972/2).

K. Sasse (Bayer AG), 'Chemischer Pflanzenschutz-gestern, heute und morgen.' Angew. Chem. 84, 271 (1972).

Noboru Shindo, Tokyo Org. Chem. Ind. Ltd., 'The Present Situation of Agricultural Chemicals in the Chemical Industry of Japan'. Japan Pesticide Information, No. 7, p. 5 (April 1971).

O. Siegel, 'Umweltsbelastung durch Pflanzenschutz und Düngemittle.' Studientagung 'Landwirtschaft-Umweltschutz', Bonn (6-7.11.1972).

Gemeinsame Erklärung unabhängiger Wissenschaftler, 'Bedenken gegen den HerbizideEinsatz'. Allg. Forst-Zeitschrift Nr. 3, 30-31, 33-35 (19 January, 1974).

EIRMA (European Industrial Research Management Association), 'The Changing Emphasis in Industrial Research and Development'. Conference Report, EIRM A/72.28. Paris (March 1972).

'Chemicals \& Health', Report of the Panel on Chemicals and Health of the [US] President's Science Advisory Committee, Chapters 7, 8, 12. (September 1973). 